\title{
Education of the Professional Accountant: An Empirical Study
}

\author{
M. RAI KAPOOR* and K. HUNG CHAN**
}

\begin{abstract}
This paper (1) reviews the literature related to the educational needs of the professional accountant, including several major studies done in the United States, and the accreditation standards of the American Assembly of Collegiate Schools of Business (A.A.C.S.B.) and (2) investigates empirically the perceptions of Canadian accounting educators and practitioners of the educational needs of professional accountants to determine the extent to which these needs are being fulfilled by the current university undergraduate programs in Canada.

The literature review confirms the theme that accountants should be broadly educated as well as being technically competent. A calendar review of eleven major Canadian universities provides an indication of the current structure of undergraduate accounting programs in Canada. An opinion survey of educators and practitioners suggests a rather different structure. Among other results, respondents of the survey suggested a higher percentage of general education be included in undergraduate accounting programs especially for certain Ontario and Quebec universities. A greater emphasis should be placed on English language and composition than currently prevails in many major universities. It is hoped that the analysis will prove useful to those involved in curriculum design at the baccalaureate level.
\end{abstract}

\section{RÉSUMÉ}

L'auteur (1) passe en revue différents ouvrages relatifs à la formation requise pour les comptables professionnels, notamment quelques études importantes réalisées aux États-Unis ainsi que les normes d'admission de l' "American Assembly of Collegiate Schools of Business" (A.A.C.S.B.) et (2) étudie empiriquement la façon dont les professeurs de comptabilité et les comptables canadiens conçoivent la formation requise pour l'exercice de la profession, dans le but de comparer leurs opinions aux différents programmes de premier cycle actuellement en vigueur au Canada.

* Assistant Professor of Accounting, Department of Accountancy, Concordia University, Montreal, Quebec

** Associate Professor of Accounting, Graduate School of Management, University of California, Riverside, California 
La recension des écrits révèle que les futurs comptables doivent recevoir une solide formation générale tout autant qu'une formation à leur domaine de spécialité. Une analyse des annuaires de neuf grandes universités canadiennes montre la structure actuelle des programmes de premier cycle, du reste contredite par un sondage d'opinions mené auprès d'enseignants et de praticiens. Les enquêtés, en effet, ont notamment proposé d'intensifier la formation générale dans les programmes de comptabilité de premier cycle, en particulier dans certaines universités ontariennes et québécoises; ils recommandent de mettre davantage l'accent sur la langue, la composition et la littérature anglaises. Cette étude devrait se révéler utile pour les spécialistes chargés d'élaborer les programmes de baccalauréat.

\section{INTRODUCTION}

Is today's education designed to prepare accountants to meet the challenges of the future? What should be the common body of knowledge prescribed for those aspiring for a career in professional accountancy? There are no categorical answers. These are indeed highly controversial questions. Of late, both businessmen and educators have been increasingly concerned with the merits of professional education on the one hand and general education on the other, and more importantly with the relative status that should exist between the two in undergraduate accounting programs. Obviously, an inadequate education will eventually show up in a lowering of the quality of services offered by professional accountants. It is, therefore, important to examine the adequacy of university undergraduate accounting programs in preparing students to become professional accountants. It can hardly be overemphasized that the future of the accounting profession in our rapidly changing society will be determined not only by the profession's adaptability and utilization of the expanded opportunities, but also by the intellectual vigour, calibre, and skill of its members (Carey, 1965).

The purpose of this paper is (1) to review the literature related to the educational needs of the professional accountant, including several major studies done in the U.S., and the accreditation standards of the American Assembly of Collegiate Schools of Business (A.A.C.S.B.), and (2) to study empirically the perceptions of Canadian accounting educators and practitioners of the educational needs of professional accountants to determine the extent to which these needs are being fulfilled by the current Canadian university undergraduate programs with a concentration in accounting.

Canada was chosen in this study because the concern about professional accounting education is widespread in Canada (Rosen, 1978; Dewhirst, 1976). Unfortunately, there has been no empirical study of this kind in recent years. The studies sponsored by the Canadian Academic Accounting Association (C.A.A.A.) and the Institute of Chartered Accountants (I.C.A.), Alberta, Canada, are of a different nature and will be explained later. Furthermore, in view 
of the close ties between the U.S. and Canadian academic and business environments, a comparative analysis can be useful to those involved in curriculum design at the baccalaureate level.

The remainder of this paper is arranged as follows. The next section presents a review of the literature, including the major American studies. In the third section, calendars of selected Canadian universities from all major provinces offering a baccalaureate degree with a concentration in accounting are analyzed. In the fourth and fifth sections, the survey and its findings are presented, discussed, and compared with other studies. The sixth and final section includes some concluding remarks.

\section{LITERATURE REVIEW}

For over two decades, there has been concern about the relatively narrow scope of undergraduate education in schools of business. The ascendancy of professional education over the years has dimmed the importance of general education in the university curricula. A number of studies conducted under the auspices of the American Accounting Association (A.A.A.), the Ford Foundation, the Carnegie Corporation of New York, the American Institute of Certified Public Accountants (A.I.C.P.A.), the Canadian Academic Accounting Association (C.A.A.A.), the Institute of Chartered Accountants of Alberta (I.C.A., Alberta), individual authors, and the accreditation standards stipulated by the American Assembly of Collegiate Schools of Business (A.A.C.S.B.) for accounting programs have pointed to the need for a balance between the two types of education. Without de-emphasizing the need for a specialized knowledge which the professional accountant must possess as an expert in the field of accounting, it has been suggested that he should be broadly educated to enable him to respond to the challenges and adjustments called for by a changing society. The major recommendations of these organizations and authors are summarized below:

\section{(A) A.A.A. Committees}

In 1954, the American Accounting Association's Committee on Standard Rating stated the following three objectives of professional accounting education: (1) Educating the Citizen; (2) Education in Business; and (3) Education in Accounting. It recommended a program divided into 50 percent liberal arts studies, 25 percent in general business, and 25 percent in accounting; subsequent committees of the A.A.A. endorsed this composition of the undergraduate program (A.A.A., 1960).

In 1963, A.A.A. set up the Committee on Courses and Curricula-General with the objective of developing a program of general education and general business knowledge for an accounting major. The committee analyzed the qualities required for a successful career in accounting and the role of university education in the development of these qualities. It recommended that five categories of 
knowledge, other than accounting, comprising $75-80 \%$ of course work in an accounting major, be included in the college curriculum (A.A.A., 1964). These five categories include basic skills in logic (e.g., philosophy, logic, etc.), communicative skill (e.g., composition, foreign language, etc.), socio-political framework of business (e.g., political science, law, etc.), cultural and ethical values (e.g., art, history, ethics, etc.), and general business functions (e.g., finance, production, marketing, etc.). The committee noted: "The man we are trying to develop - a professional accountant and business leader - needs these skills, probably to a higher degree than he needs the technical and specialized skills more commonly associated with the accounting profession ... if he is to cope with the business complexities and social changes that will occur in the years ahead." (A.A.A., 1964).

In 1976, the A.A.A. Committee on Professional Examinations (A.A.A., 1976) published a survey of schools of business on the level of contents of various topics included in the schools' undergraduate accounting programs. Hadley and Balke (1979) pursued the investigation further by comparing the perceptions of CPA practitioners on the content level of 72 topics with the ufferings in the undergraduate accounting programs. They discovered significant differences between the two on a number of topics, suggesting the need for better communication between accounting academics and practitioners.

\section{(B) Ford and Carnegie Reports}

Two studies sponsored by the Ford Foundation and the Carnegie Corporation of New York had been published simultaneously in 1959 (Gordon \& Howell, 1959; Pierson et al., 1959). Their recommendations are summarized in Table 1. Both studies recommended that roughly half of the four-year undergraduate work be devoted to general non-business subjects. As compared to Ford, Carnegie laid more emphasis on general education, less on business courses and slightly more on work in accounting.

\section{(C) A.I.C.P.A. Study}

In 1967, the American Institute of Certified Public Accountants published a study entitled, "Horizons for a Profession," defining a common body of knowledge required for beginning C.P.A.'s (Roy \& MacNeill, 1967). The study recommended (1) emphasis on conceptual learning, (2) more course work in mathematics, statistics, and the computer, and (3) enhanced general education with a view to producing cultivated well-rounded individuals as professional accountants. The Beamer Committee report (AICPA, 1969) later endorsed Horizon's findings.

(D) A.A.C.S.B.

In its latest accreditation standard for baccalaureate programs with a concentration in accounting, A.A.C.S.B. (1983) recommends that such programs should 
Table 1

FORD AND CARNEGIE REPORTS:

Percentage Allocation of Student Time

\begin{tabular}{l||c|c|c}
\hline \multicolumn{1}{c||}{ Reports } & $\begin{array}{c}\text { Liberal Arts } \\
\text { (Including Math.) }\end{array}$ & $\begin{array}{c}\text { General Business } \\
\text { (Including } \\
\text { Economics) }\end{array}$ & Accounting \\
\hline Ford Foundation & $45-57.5$ & 45 & 10 \\
Carnegie Corporation & $52.5-60$ & $32.5-35$ & $10.0-12.5$ \\
\hline
\end{tabular}

"afford reasonable choice for students by making available a wide-ranging group of courses in general education, business administration, and the discipline of accounting." In particular, it is stipulated that a student's minimum program should include:

1. at least 40 percent in general education, including English composition, behavioural sciences and humanities, political and legal environment of business and society, and mathematics and statistics.

2. at least 25 percent in general business, including economics and principles of financial and management accounting, and management information systems. (As shown in Table 8, the percentage becomes 20 if the introductory accounting courses are excluded from general business.)

3. at least 15 percent but not more than 25 percent in the discipline of accounting. (These percentages become 20 and 30 if the introductory accounting courses are included in accounting.)

A survey by Brown and Balke (1983) indicated that A.A.C.S.B. accreditation standard is of interest to a large number of U.S. business schools and these schools most frequently offer accounting credit hours in line with the standard.

\section{(E) C.A.A.A. Study}

An empirical study on Canadian accounting education was conducted under the auspices of Canadian Academic Accounting Association (Beechy, 1980). Unlike others, this study focussed on the assessment of accounting courses only rather than on the overall structure of baccalaureate programs with a major in accounting. Among other recommendations, the study suggested increased emphasis on conceptual teaching and accounting theory courses rather than on technical details. The study pinpoints the dominance of the procedural, preparer-oriented approach in the introductory courses, as opposed to the conceptual or user-oriented approaches. The Education Committee of the C.A.A.A. endorsed the findings of the study in its report to the members in March 1981 (C.A.A.A., 1981).

In his book on the future of accounting in a changing society, Bedford (1969) also pleaded for a greater emphasis on the teaching of concepts rather than rules in the university professional education programs. According to him, this is important to facilitate the changes and adjustments in accounting called for by a 
changing society. A recent study by Amernic and Beechy (1984) supports this theme.

\section{(F) I.C.A., Alberta Report}

Another report on Canadian accounting education is that of the Special Committee on Chartered Accountant Education in Alberta (I.C.A., 1982). This committee was established by the Institute of Chartered Accountants of Alberta in 1979 to identify means of improving the quality and increasing the quantity of students wishing to enter the chartered accountancy profession in Alberta. Though provincial in scope, the findings of the committee have nationwide implications and are in line with the C.A.A.A. study.

Numerous other authors have also commented directly or indirectly on professional accounting education. Many have voiced concern over the tendency toward overspecialization in undergraduate programs and advocated the importance of general education including literature, languages, history, and international affairs (Hesburgh, 1981; Leavis, 1965; Newman, 1976; Sloan, 1983; Whitehead, 1966). According to them, a liberally educated man acquires the ability to think clearly, logically, deeply, and widely. He is better able to bring professional knowledge and training into effective relationships with informed intelligence, humane culture, social conscience, and political will. Without such an enlarged human experience and a sense of values, an accountant may be tempted to act as a manipulator of the numbers, instead of seeking fairness in financial assessments; or similarly, a doctor may forget the dignity of the human and treat him as a mechanic would treat an engine. Accountants are often called upon to provide leadership with respect to their fellow men as well as to contribute the fruits of their functional competence to the general welfare. The exercise of inspired and responsible leadership calls for an understanding of human aspirations and values. Such an understanding can be facilitated by liberal education. In a similar theme, it was suggested that CA firms should hire certain non-accounting graduates who, after going through a series of "make-up" accounting courses, can become competent CAs and creative partners (Luscombe, 1983).

In short, this review of literature in accounting education has underlined a key point: there has been a continuing concern both on the part of practitioners and academics alike about the state of accounting education in North America. The idea is to provide an appropriate broad-based education for future growth for those aspiring to adopt a career in professional accountancy.

\section{UNIVERSITY CALENDAR REVIEW}

A comparative statement of credit requirements for a baccalaureate degree in commerce with a major in accounting as specified by eleven universities in their calendars for the academic year 1983-84 is given in Table 2. At least one major university from each province was selected provided that it has an official major or 


\section{TABLE 2}

\begin{tabular}{|c|c|c|c|c|c|c|c|c|c|c|c|c|c|c|}
\hline & \multicolumn{2}{|c|}{ Accounting } & \multicolumn{2}{|c|}{$\begin{array}{c}\text { General } \\
\text { Education } \\
\text { (including non- } \\
\text { business } \\
\text { electives } \\
\end{array}$} & \multicolumn{2}{|c|}{ Economics } & \multicolumn{2}{|c|}{$\begin{array}{c}\text { General Business } \\
\text { (including business } \\
\text { electives) }\end{array}$} & \multicolumn{2}{|c|}{$\begin{array}{c}\text { Math/ } \\
\text { Statistics }\end{array}$} & \multicolumn{2}{|c|}{$\begin{array}{c}\text { Free } \\
\text { Electives } \\
\end{array}$} & \multicolumn{2}{|l|}{ Total } \\
\hline & Credits & $\underline{x}$ & Credits & $\underline{6}$ & Credits & $\frac{g}{2}$ & Credits & $\underline{x}$ & Credits & $\underline{\not}$ & Credits & $\underline{\not x}$ & Credits & $\%$ \\
\hline 1. Concordia & 36 & 40 & - & - & 6 & 7 & 33 & 36 & 6 & 7 & 9 & 10 & 90 & 100 \\
\hline 2. McGill & 21 & 23 & 12 & 13 & 9 & 10 & 33 & 37 & 9 & 10 & 6 & 7 & 90 & 100 \\
\hline 3. Ot tawa & 36 & 28 & 18 & 14 & 9 & 7 & 37 & 29 & 13 & 10 & 15 & 12 & 128 & 100 \\
\hline 4. Waterloo & 63 & 49 & 21 & 16 & 12 & 9 & 18 & 14 & 9 & 7 & 6 & 5 & 129 & 100 \\
\hline $\begin{array}{l}\text { 5. British } \\
\text { Columbia }\end{array}$ & 36 & 26 & 30 & 22 & 6 & 4 & 45 & 33 & 12 & 9 & 9 & 6 & 138 & 100 \\
\hline 6. Simon Fraser & 21 & 18 & 31 & 26 & 9 & 7 & 14 & 12 & 12 & 10 & 33 & 27 & 120 & 100 \\
\hline 7. Alberta & 24 & 20 & 24 & 20 & 15 & 12 & 33 & 28 & 6 & 5 & 18 & 15 & 120 & 100 \\
\hline 8. Calgary & 21 & 18 & 24 & 20 & 6 & 5 & 45 & 37 & 12 & 10 & 12 & 10 & 120 & 100 \\
\hline 9. Dalhousie & 30 & 25 & 30 & 25 & 9 & 8 & 39 & 32 & 12 & 10 & - & - & 120 & 100 \\
\hline 10. Manitoba & 24 & 19 & 24 & 19 & 6 & 5 & 60 & 48 & 12 & 9 & - & - & 126 & 100 \\
\hline 11. Saskatchewan & 33 & 27 & 21 & 17 & 12 & 10 & 30 & 25 & 9 & 8 & 15 & 13 & 120 & 100 \\
\hline
\end{tabular}

Note 1: A few universities list requirements in terms other than the numbers of credits needed to complete the degree. For purposes of this table, the following equivalencies were established to help comparison: University of Waterloo: one term course was converted to three semester credits;

University of British Columbia: $1-1 / 2$ units were converted to three semester credits; University of Calgary: one full course was converted to six semester credits; Dalhousie University: one full course was converted to six semester credits.

Note 2: University of British Columbia, University of Calgary, and Dalhousie University require evidence of proficiency in English prior to admission to the program or award of the degree.

Note 3: The entrance requirment for Concordia and MCGill Universities is a Diploma of Collegial Studies at a C.E.G.E.P. in Quebec or equivalent. 
TABLE 3

Sumary of the PERCENTAge of STUDENT IIME dEVOTED TO SUBJECT AREAS IN THE VARIOUS PROGRAMS

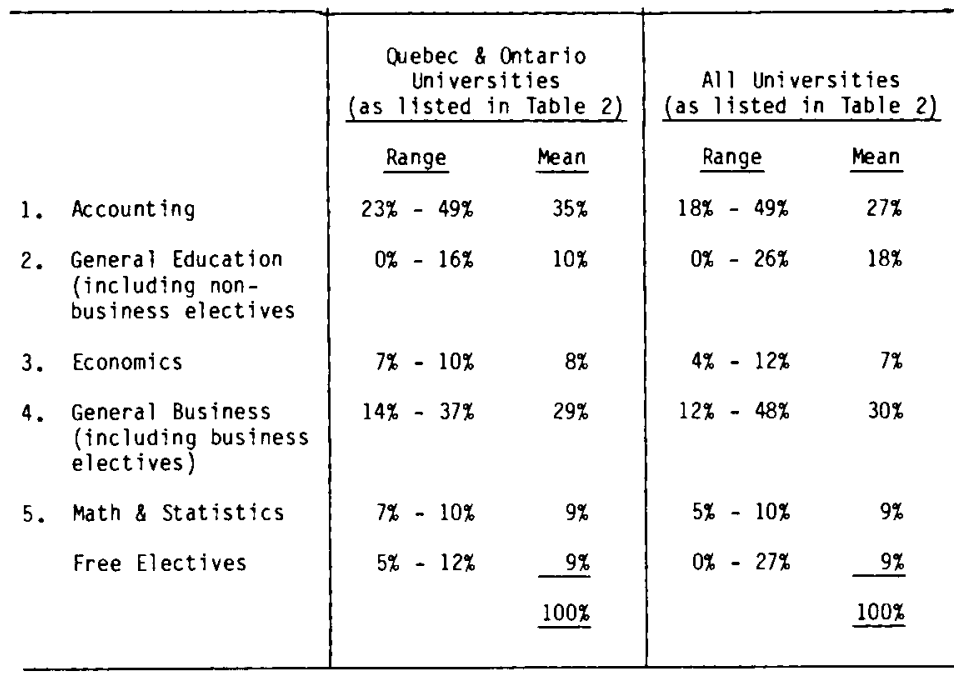

concentration in accounting. Such a calendar review provides an overview of the structure of the degree programs in terms of the percentage of student time devoted to five different areas of education. (It may also be said that the calendar review reveals the contents of the degree program in terms of the relative weightings for accounting, non-accounting, business and non-business courses. However, in this paper, we do not deal with the detailed topics covered in accounting courses. For such a study, see Beechy (1980).)

The results of the calendar review will later be compared with the recommendations of the various studies, A.A.C.S.B. standard and the results of an opinion survey on the perceptions of practitioners and educators on what they believe the structure should be (see Section IV). A comparison can also be made among the eleven universities to see the degree of consensus or diversity in their programs.

Table 3 reveals a wide disparity in the programs of the various institutions. Although the analysis is limited because we do not know how students may decide on the free electives, one can use the analysis to focus on the state of general education in professional accounting programs. As can be observed from Tables 2 and 3 , certain universities allow students to obtain a baccalaureate accounting degree with rather limited requirement in the general education area. Given the importance of general education as stated earlier, one may question whether many of our undergraduate accounting programs have adequately emphasized the value of such education for accountants.

\section{THE OPINION SURVEY}

What are the opinions of accounting educators and practitioners about an appropriate undergraduate program leading to a baccalaureate degree with a major 
TABLE 4

RESPONSES OF THE SAMPLE GROUPS

\begin{tabular}{|c|c|c|c|c|c|c|c|c|c|c|c|c|c|c|}
\hline \multirow{3}{*}{$\begin{array}{l}\text { Respondent } \\
\text { Classification } \\
\text { Number \& Percentage } \\
\text { o: Sample Size }\end{array}$} & \multicolumn{2}{|c|}{$\begin{array}{l}\text { Grand } \\
\text { Total } \\
\end{array}$} & \multicolumn{2}{|c|}{ Erducators } & \multicolumn{10}{|c|}{ Practitioner } \\
\hline & & & & & Large & Est* & Larg & New & Sma l & Est* & Sma l & $\mathrm{New}^{\star}$ & & \\
\hline & $\#$ & $\%$ & 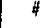 & $\%$ & $\#$ & $\%$ & $\#$ & $\%$ & $\#$ & $\%$ & $\#$ & $\%$ & $\#$ & \% \\
\hline Sample Size & 145 & 100 & 49 & 34 & & & & & & & & & 96 & 66 \\
\hline Usable Returns & 76 & 52 & 20 & 14 & 24 & 16 & 11 & 8 & 11 & 8 & 10 & 6 & 56 & 38 \\
\hline Nonusabie Returns & 7 & 5 & 1 & 1 & & & & & & & & & 6 & 4 \\
\hline Not Returned & 62 & 43 & 28 & 19 & & & & & & & & & 34 & 24 \\
\hline
\end{tabular}

* Refers to Established Practitioners from Large Firms, Newer Practitioners from Large Firms, etc.

in accounting, as a preparation for a career in professional accountancy? The survey instrument used was a questionnaire divided into four parts: part I related to personal data; parts II and III covered data relating to employment, size of firm, specific interest of respondents, etc., and were to be completed by academics and practitioners, respectively; part IV to be completed by all respondents had two questions; in question one, respondents were asked to rank order various topics classified under five subject areas, namely, (1) accounting, (2) general education, (3) economics, (4) general business, and (5) mathematics and statistics. In question two, they were asked to indicate the percentage of student time that should be devoted to each subject area. The questionnaire was pre-tested through a pilot survey of 10 educators and 10 practitioners. The results of the pilot study indicated that a study based on larger samples was feasible. A few ambiguities in the original questionnaire were also discovered. The questionnaire was revised accordingly.

Based on the experience of the pilot study, it was decided to take a random sample of 145 persons with about $1 / 3$ educators and $2 / 3$ practitioners. The initial and follow-up surveys were conducted in early 1983. The educators were chosen from 18 accounting faculties across the provinces of Ontario and Quebec, while the practitioners were chosen from the total population of Chartered Accountants registered in Metropolitan Toronto. (Ontario and Quebec have the largest cluster of educators with widely different background. Similarly, Metro Toronto has the largest cluster of professional accountants practicing almost all aspects of accounting and auditing with widely different levels of experience from firms of all sizes. Thus, our choice of samples is consistent with the theory of cluster sampling (Cochran, 1963). Names and addresses of practitioners were obtained from the Directory of Canadian Chartered Accountants (CICA, 1981).)

A breakdown of the responses is shown in Table 4 . The overall usable response rate was $52 \%$. To determine whether there was any non-response bias, we 
classified respondents into early and late respondents. Late respondents were those who answered the follow-up survey. Late respondents were assumed to hold views similar to those of the non-respondents. A comparison of the results of early respondents with those of late respondents provided no indication of any significant non-response bias in the responses to the questionnaire (Oppenheim, 1966).

For analytical purposes, practitioners were classified into four categories: (1) established practitioners from large firms; (2) newer practitioners from large firms; (3) established practitioners from small firms; and (4) newer practitioners from small firms. "Established" practitioners are defined as those who have obtained their CA certification for over ten years; firms employing ten or more professional accountants are defined as "large."

Practitioners from large firms as compared with those from small firms may place relatively more emphasis on accounting courses because of the specialized nature of their activities and the relative complexities of accounting or auditing problems faced by large accounting firms in the audit of conglomerates. Established practitioners as compared with newer practitioners may place more emphasis on general education because they are more experienced and know how to be successful accountants. Furthermore, established practitioners might have had more general education when they went through universities. A study of literature reveals that with the ascendancy of professional education, there has been a trend toward the slackening of interest in general education.

\section{(A) Results and Analysis: Ranking of Topics in Each Subject Area}

Tabel 5 shows the ranking of topics for each of the five subject areas in order of median values. (The highest ranking in each area is " 1 ." In case of a tie, the topic with a smaller inter-quartile range was ranked ahead of the others.) Rankings by mean values provide essentially the same results. To interpret the results in Table 5 , for example, the median ranking of introductory accounting is 2 meaning that $50 \%$ of the respondents ranked the course higher than or equal to number 2 and $50 \%$ lower than number 2 . The 75 th percentile of the course is 4 meaning that $25 \%$ of the respondents ranked the course higher or equal to number 4 and $75 \%$ ranked it lower than number 4 . The inter-quartile range is the difference between the 25 th and the 75 th percentiles and is a measure of the diversity of opinion regarding the importance of the topic.

Spearman rank correlation coefficients (Siegel, 1978) were calculated to assess the degree of consensus in the rankings of topics by the different groups of respondents. Table 6 shows that all the correlation coefficients have a value of greater than 0.70 and are statistically significant at 0.05 level. This means that there is a consistently high degree of consensus in the rankings of topics within a subject area by the different groups of respondents. It should also be pointed out that English language in the General Education area was ranked first by all groups, a unanimity absent in other topics. To obtain further insight into the survey results, we take each subject area at a time and study the rankings of the related courses. 
TABLE 5

RANKINGS OF ALL RESPONDENTS IN DECREASING ORDER OF IMPORTANCE BY MEDIAN WITHIN EACH SUBJECT AREA

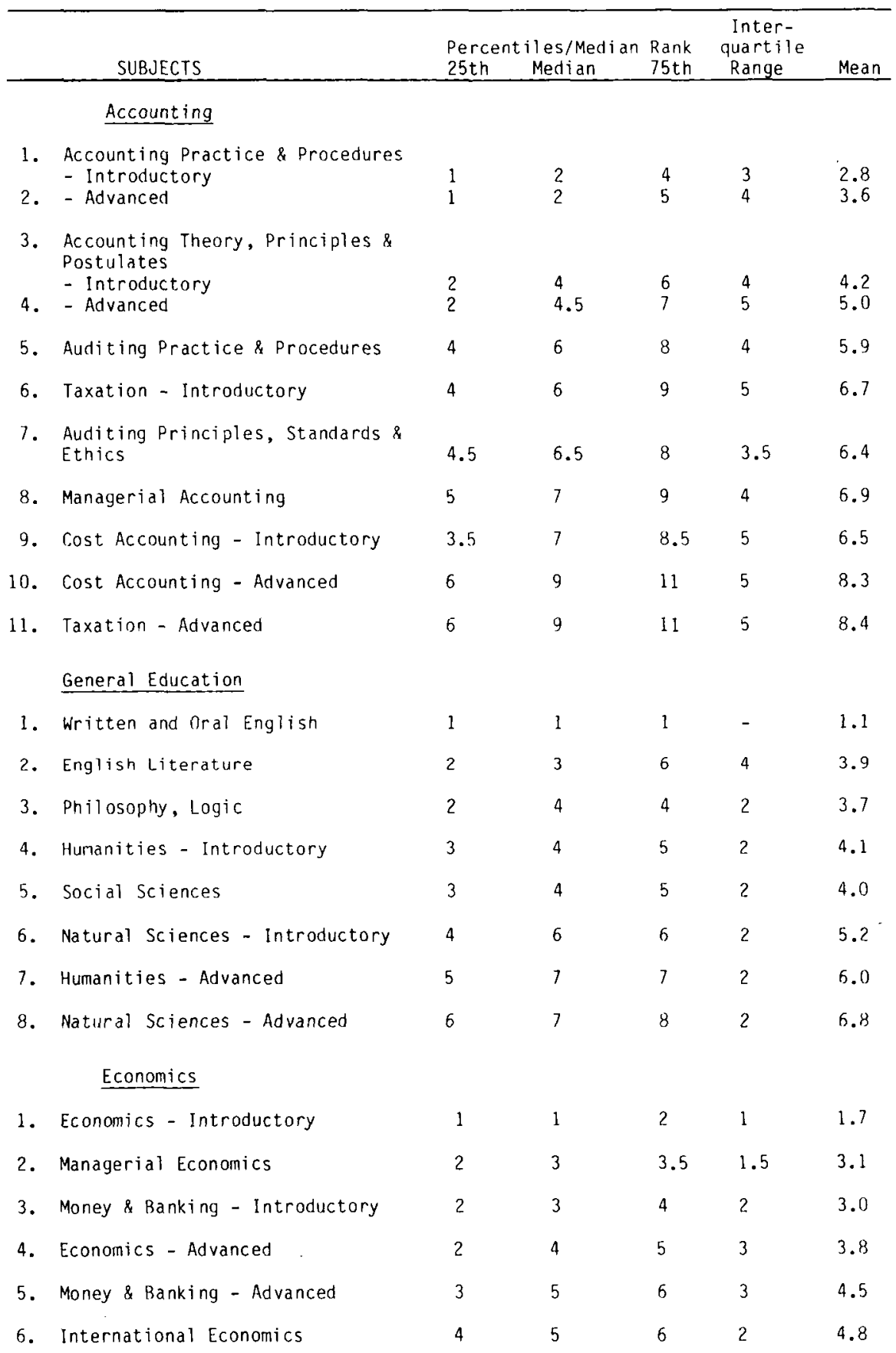


TABLE 5 (Continued)

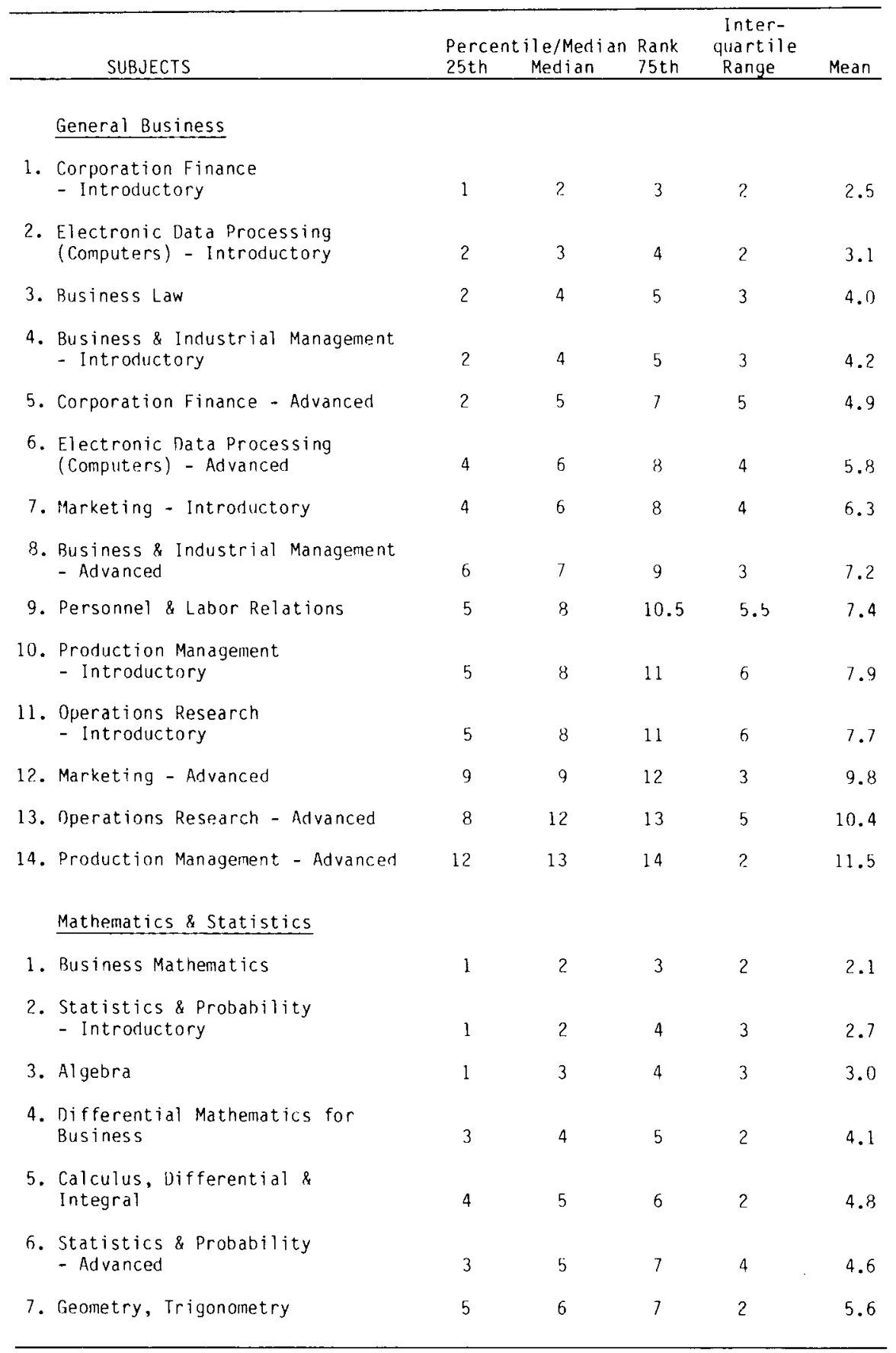


RESPONDENT CLASSIFICATION AND ASSOCIATED RhO VALUES (CORRELATION) IN EACH SUBJECT AREA

EDUCATORS

$$
\text { VS. }
$$

PRACTITIONERS

\section{PRACTITIONERS}

Large-Est ${ }^{\star}$ Large-Est ${ }^{\star}$ Large-Est ${ }^{\star}$ Large-Newer Large-Newer Small-Est ${ }^{\star}$

$$
\text { vs. }
$$

arge-Newer
Small-Newer

\author{
vs.
}

vs. Small-Newer Small-Newer

\section{Subject Area:}

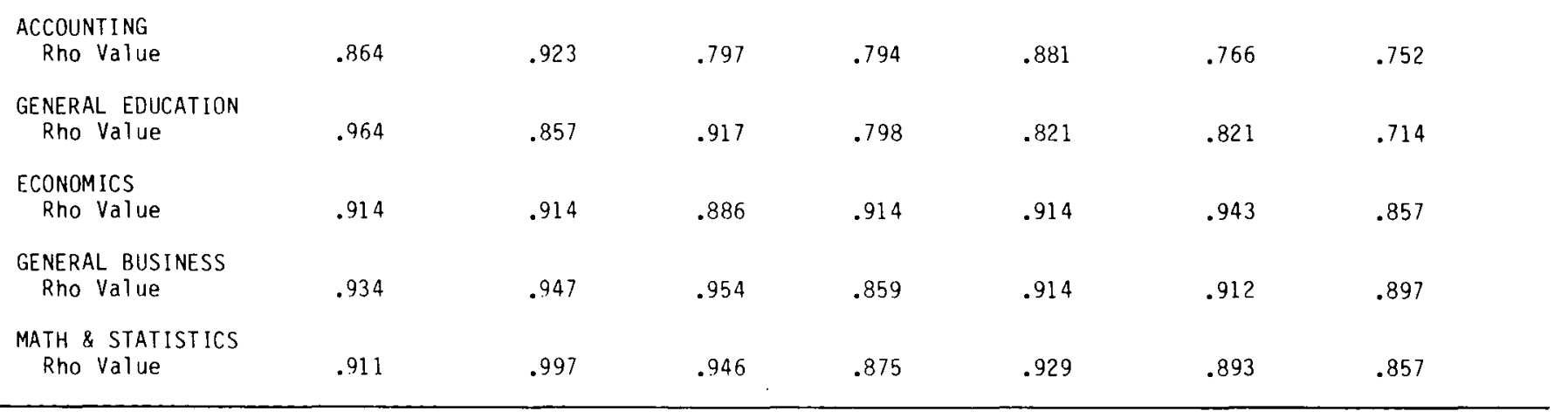

*Est. denotes Established.

NOTE: A t or a Rs statistic was used depending on the degrees of freedom to test the significance of the correlation coefficients. It was found that all the coefficients were significant at 0.05 level. See, Sidney Siegel, Nonparametric Statistics for the Behavioral Sciences, McGraw Hill, 1956. 


\section{Accounting}

Of the eleven courses listed in this category, Accounting Practice and Procedures and Accounting Theory, Principles and Postulates - both introductory and advanced - were roughly in the upper third of the rankings. The importance attached to the theory courses is in concurrence with the latest thinking on the subject and the recommendations of the C.A.A.A. study discussed earlier. No significant difference in rankings by educators and practitioners was detected as indicated in Table 6.

\section{General Education}

The top-most rank accorded to written and oral English by all respondents bears out the findings of other studies as mentioned in the literature review. There has been a long history of complaints about the ability of professional accountants to write, read, and speak effectively. It might be noted that written and oral English, English Literature, Philosophy, Logic, Introductory Humanities and Social Sciences were ranked in roughly the upper half of the courses included in this subject area. No significant difference in rankings by the various categories of respondents was found at .05 level of significance.

\section{Economics}

This subject area contained six courses. It is interesting to note that Money and Banking - Introductory was ranked third by the respondents. Not many universities, however, include it as a required course. For example, only one school listed in Table 2 has a required course in Money and Banking.

\section{General Business}

It is important to note the high ranking accorded to Electronic Data Processing Introductory, next to Corporation Finance - Introductory. Electronic Data Processing - Advanced is ranked sixth among the 14 courses listed under general business. This importance attached to electronic data processing by all respondents is borne out by the findings of various studies. The growing use of computers in business and its importance to the accountant's professional practice can hardly be over-emphasized.

It is difficult to say why Operations Research - Introductory and Advanced were relegated almost to the bottom of the rankings. It will be hard to minimize the importance of these courses in the common body of knowledge for the professional accountant of the future. One reason for the low ranking may be the difficulty in digesting the complicated mathematical materials in these courses. Another reason may be that these courses are often taught by instructors who have little knowledge about the application of the materials to accounting or related issues.

\section{Mathematics and Statistics}

Business Mathematics, Statistics and Probability - Introductory, Algebra and Differential Mathematics for Business were ranked by the respondents in roughly 
TABLE 7

RESPONDENTS' PERCEPTION OF STUDENT TIME THAT SHOULD IDEALLY BE DEVOTED TO VARIOUS SUBJECT AREAS

\begin{tabular}{|c|c|c|c|c|c|c|c|}
\hline $\begin{array}{l}\text { Respondent } \\
\text { Classification }\end{array}$ & $\begin{array}{c}\text { All } \\
\text { Respondents }\end{array}$ & Educators & & & ractitioners & & \\
\hline $\begin{array}{l}\text { Percentage of } \\
\text { Time }\end{array}$ & 工 & 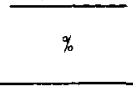 & $\underset{\%}{\operatorname{arge} / \text { Est* }}$ & $\underset{\%}{\text { Large/New }}$ & Smal| ${ }_{\%}$ & $\underset{\%}{\text { SmaT }}$ & $\begin{array}{c}\text { AाT } \\
\%\end{array}$ \\
\hline \multicolumn{8}{|l|}{ Subject Area } \\
\hline Accounting & 35 & 34 & 38 & 42 & 25 & 35 & 36 \\
\hline General Education & 20 & 20 & 21 & 14 & 24 & 17 & 20 \\
\hline Economics & 12 & 14 & 12 & 10 & 16 & 11 & 12 \\
\hline General Business & 20 & 19 & 16 & 22 & 22 & 25 & 20 \\
\hline $\begin{array}{l}\text { Ma thematics \& } \\
\text { Statistics }\end{array}$ & 13 & 13 & 13 & 12 & 13 & 12 & 12 \\
\hline TOTAL & 100 & 100 & 100 & 100 & 100 & 100 & 100 \\
\hline
\end{tabular}

^Est. denotes F.stablished.

the upper half of the courses listed in this subject area. These courses were commonly included in the course offerings of the majority of the institutions surveyed.

\section{(B) Results and Analysis: Percentage of Student Time That Should Be Devoted to Various Subject Areas}

Respondents were asked to indicate the percentage of student time that should ideally be devoted to the various subject areas. These results are shown in Table 7 by respondent class.

From Table 7 , it is interesting to observe that despite their differences in educational background and in the nature of their work, accounting educators and practitioners on the whole have a remarkably similar perception of the ideal distribution of student time over the five subject areas. However, there were some differences of opinion among the practitioners themselves. The newer generation of accountants de-emphasized general education, especially those working in large firms who would like to place more emphasis on accounting at the cost of general education. The newer generation working in small firms tended to attach more importance to accounting and general business. In contrast, the established practitioners emphasized more on general education, especially those working in small firms. An emphasis on general education by the established practitioners can be a reflection of their maturity and perhaps, in some cases, their own education. There is evidence that general education was given more emphasis in the past. In fact, a trend toward the slackening of interest in general education has been observed. According to Levine (1978) there has been evidence that colleges have tended to move general education courses from core courses toward free electives. 
Again, one would notice a streak of large-small firm syndrome. Both established and newer practitioners working in large firms seemed to place relatively more emphasis on concentration in the accounting area. This could easily be explained by the specialized nature of activities in large firms. Those working in small firms attached relatively more importance to education in economics and general business areas. This could be due to the absence of a division of labour or specialized divisions in small firms. Many are supposed to be capable of performing a variety of accounting functions, including financial accounting and reporting, audit and management service functions adequately; theirs is a do-it-all approach.

\section{A COMPARATIVE ANALYSIS}

How do the perceptions of respondents and the recommendations of various U.S. studies of the subject compare with the current university curricula especially in the controversial general education area? Table 8 presents a comparative view of the percentage of student time recommended by the various studies, the A.A.C.S.B., and the respondents to our survey on the major subject areas comprising the common body of knowledge of the professional accountant, and the current status of Canadian university programs offering a baccalaureate degree with a concentration in accounting. The percentages for the respondents are the average of all respondents for each subject area. The percentages for the university curricula are the average percentages of the universities included in Table 2. The major differences are explained below.

\section{Accounting}

Observe that both the A.A.A. (25\%) and the A.A.C.S.B. (20-30\%) place relatively more emphasis on specialization in accounting than the Ford (10\%) and Carnegie (10-12.5\%) studies. The current average Canadian university program (27\%) compares well with the A.A.A. and A.A.C.S.B. recommendations, although the respondents $(35 \%)$ perceive more time allocated to this area. This inclination towards further specialization could be due to perception of accounting practitioners of the increasing complexity of accounting issues.

\section{General Education}

In the controversial general education area, including mathematics/statistics, recommendations of the various studies and the A.A.C.S.B. range from at least $40 \%$ to $60 \%$ of student time. The A.I.C.P.A. study stressed the importance of an adequate preparation in this area. The respondents perceive $33 \%$ as adequate, as against the average of $27 \%$ of student time being devoted to general education by the eleven Canadian universities. Only $19 \%$ of student time is being allocated by the Quebec and Ontario universities in Canada. This is important because over $50 \%$ of Canadians live in those two provinces, with the greatest concentration of Canadian business and educational institutions. 


\begin{tabular}{|c|c|c|c|c|c|c|c|c|}
\hline & & \multirow[b]{2}{*}{ Ford } & \multirow[b]{2}{*}{ Carnegie } & \multirow[b]{2}{*}{ A.A.A. } & \multirow[b]{2}{*}{ A.A.C.S.B. } & \multirow[b]{2}{*}{ Al1 Respondents } & \multicolumn{2}{|c|}{ Current Status } \\
\hline & & & & & & & $\begin{array}{c}\text { Quebec \& Ontario } \\
\text { Universities } \\
\text { (as listed in } \\
\text { Table 2) } \\
\end{array}$ & $\begin{array}{c}\text { All } \\
\text { Universities } \\
\text { (as listed in } \\
\text { Table 2) } \\
\end{array}$ \\
\hline 1. & Accounting & $10 \%$ & $10.0-12.5 \%$ & $25 \%$ & $20-30 \% \star$ & $35 \%$ & $35 \%$ & $27 \%$ \\
\hline 3. & $\begin{array}{l}\text { General } \\
\text { Business } \\
\text { including } \\
\text { Economics }\end{array}$ & $45 \%$ & $32.5-35 \%$ & $25 \%$ & $\begin{array}{l}\text { At least } \\
20 \%\end{array}$ & $32 \%$ & $37 \%$ & $37 \%$ \\
\hline
\end{tabular}

* For comparative purposes the figures have been adjusted by transferring five percentage points representing introductory courses in financial and management accounting from General Business to Account ing. 
It is interesting to note that although the respondents place relatively less emphasis on general education than the U.S. studies, they perceive a much higher percentage than what is being offered in Canadian universities, particularly the Quebec and Ontario universities. If we exclude mathematics/statistics from the general education area, the respondents perceive twice as much time as presently allocated by the average of the four universities in these two major provinces.

It should be pointed out that certain general education topics such as communication and behavioural sciences are of greater importance to professional accounting practice than others. The non-business electives offered by many universities (which we assume to be part of general education for purposes of this study) often include courses in less significant areas. For those universities, students may be able to complete their degree program with the relevant general education component far less than that indicated in Tables 2 and 8 . In fact, if one excludes the non-business electives, the compulsory general education requirement (not counting mathematics and statistics) is only $5 \%$ for the four Ontario and Quebec universities and 6\% overall. This weighting for general education is significantly less than what has been recommended by most studies and by the respondents to our survey.

\section{General Business}

The result of emphasis or de-emphasis on the first two subject areas is in turn reflected in allocation of student time to general business and economics. The recommendations of the A.A.C.S.B. and the U.S. studies range from at least $20 \%$ to $45 \%$; the respondents perceive $32 \%$ of student time as an adequate preparation in this area, which is about five percentage points lower than that offered by the average of the eleven Canadian universities. Thus, overall the Canadian universities seem to be emphasizing general business at the cost of liberal arts/general education for students.

\section{Free Electives}

Some may argue that students, by making judicious choice of electives, will be able to create a suitable general education program for themselves. This is, however, a questionable assumption. General education and for that matter, education in any field is not simply a matter of accumulating a certain number of credits here and there. Education in the true sense of the term should be based upon the principle of integration and of unification of the curriculum. There is a need to include general education in the core curriculum. A "cafeteria-style" general education program is not likely to realize the objectives of liberal education for accountants or anyone else.

In view of the highest importance attached by respondents to written and oral English in general education for accounting students, a reference to its present status in the Canadian university curricula is appropriate. It is noticed that there is a divergence between current practice and findings of the opinion survey in this area. Of the eleven Canadian university curricula which were analyzed in detail, it 
is unfortunate that only five required an introductory course in English language, literature and composition, while four universities had no offerings at all in this area in their program. Two had no offering in English language but had a semblance of English instruction in such "adapted" courses as effective business English, effective written communication and business communication, etc. It must be admitted that such courses may not be good substitutes for basic English composition and literature often offered by the English department as they do differ in orientation.

\section{SUMMARY AND CONCLUSION}

The results of this study indicate that undergraduate accounting programs in Canadian universities should be enriched by more emphasis on general education. At present, several programs require accounting and business credits which far exceed the desirable amount. It is sometimes argued that broadening the educational base may replace student time now devoted to accounting and business subjects and, thereby, adversely affect the preparation for the professional practice of accounting. "But more and more educators are coming to the conclusion that a university which concentrates on teaching students to perform the duties of a junior accountant is not making the best use of its time. Training, they say, is the profession's job; the mission of educators should be education," (Carey, 1965). Intellectual curiosity and thinking which will motivate life-long study is perhaps the best gift that a university can bestow on its students. University education should not focus on vocational training.

The respondents of the survey suggest a higher percentage of general education be included in Canadian undergraduate accounting programs especially for certain Quebec and Ontario universities. The gap between the recommendations of the U.S. studies and the average Canadian university requirement is even more significant. Furthermore, there should be more emphasis placed on English language and composition, computer-oriented courses and on developing mathematical and statistical skills for the students. As indicated in Table 5, these courses received high rankings from the respondents.

It is hoped that this study will bring into focus the inadequacy of general education in Canadian undergraduate accounting programs and prove useful to those directly or indirectly involved in curriculum design at the baccalaureate level. At present, these programs vary widely with regard to the component of liberal and general studies in their curricula. The institutions run the gamut from those providing almost no offerings in liberal studies to those in which about one-third of the instruction is outside the accounting field and its supporting disciplines. But, unfortunately, even at some major institutions, general education requirements are fulfilled largely by students electing a few scattered introductory liberal arts courses, which belie the very purpose of liberal instruction. The principle of integration, which should have the pride of place, is conspicuous by its absence in their curricula. It is high time that undergraduate professional 
accounting programs are adapted to realize the ideal set forth in the following quotation from Whitehead (1966):

What we should aim at producing is men who posses both culture and expert knowledge in some direction. Their expert knowledge will give them the ground to start from, and their culture will lead them as deep as philosophy and as high as art.

This will create the environment for the professional accountants of the future to be broadly educated and cultivated men and women.

\section{REFERENCES}

American Accounting Association (A.A.A.). Report of the Committee on the Scope of the Four Year Accounting Major. The Accounting Review, (April 1960), 203-205.

American Accounting Association (A.A.A.). Report of the Committee on Courses and Curricula General. The Accounting Review, (July 1964), 721-738.

American Accounting Association (A.A.A.). Report of the Committee on Professional Examinations. (The Accounting Review, (Supplement 1976), 1-37.

American Assembly of Collegiate Schools of Business (A.A.C.S.B.). Accreditation Standards and Interpretations for Accounting Programs. 1983.

American Institute of Certified Public Accountants (A.I.C.P.A.). Report of the Committee on Education and Experience Requirements for CPA's. 1969.

Amernic, J. \& Beechy, T. Accounting Students' Performance and Cognitive Complexity: Some Empirical Evidence. The Accounting Review, (April 1984), 300-313.

Beechy, T. University Accounting Programs in Canada: Inventory and Analysis. The Canadian Academic Accounting Association, 1980.

Bedford, N. The Future of Accounting in a Changing Society. Champaign, IL: Stipes Publishing Company, 1969, 3-15.

Brown, J., Jr. \& Balke, T. Accounting Curriculum Comparison By Degree Program of Schools Intending to Seek AACSB Accreditation. Issues in Accounting Education, (1983), 50-59.

Canadian Academic Accounting Association (C.A.A.A.). Education Committee, 1980/81. Report to the Members of the C.A.A.A.. March 31, 1981.

Canadian Institute of Chartered Accountants (C.I.C.A.). Directory of Canadian Chartered Accountants. 1981.

Carey, J. The CPA Plans for the Future. New York: The American Institute of Certified Public Accountants, 1965, 258-263.

Cochran, W. Sampling Techniques. New York: John Wiley \& Sons, 1963.

Dewhirst, J. The Intellectualization of University Accounting Education. CA Magazine, (March 1976), 72-75.

Gordon, R. \& Howell, J. Higher Education for Business. New York: Columbia University Press, 1959.

Hadley, G. \& Balke, T. A Comparison of Academic and Practitioner Views of Content Levels in the Undergraduate Accounting Curriculum. The Accounting Review, (April 1979), 383-389.

Hesburg, T. The Future of Liberal Education. Change Magazine, (April 1981), 36-40.

Institute of Chartered Accountants (I.C.A.) of Alberta. Report of the Special Committee on Chartered Accountant Education in Alberta. March 1982.

Leavis, F. Education and the University: A Sketch for an English School. London: Chattoo and Windus, 1965. 
73 Education of the Professional Accountant: An Empirical Study

Levine, A. Handbook on Undergraduate Curriculum. San Francisco: Jossey Bass Publishers, 1978, $1-27$.

Luscombe, N. Who Needs Them? CA Magazine, (December 1983), 3.

Newman, J.H. The Idea of a University Defined and Illustrated. Edited with Introduction and Notes by I.T. Ker. Oxford, England: Clarendon Press, 1976.

Oppenheim, A. Questionnaire Design and Attitude Measurement. New York: Basic Books, 1966, 34.

Pierson, F. et al. The Education of American Businessmen. New York: McGraw-Hill Book Company, 1959.

Rosen, L. Accounting Education: A Grim Report Card. CA Magazine, (September 1978), 53-66.

Roy, R. \& MacNeill, J. Horizons for a Profession. New York: American Institute of Certified Public Accountants, 1967.

Siegel, S. Nonparametric Statistics for the Behavioural Sciences. New York: McGraw-Hill Book Company, 1956, 202-213.

Sloan, D. The Education of the Professional Accountant. Journal of Accountancy, (March 1983), 56-60.

Whitehead, A. The Aims of Education and Other Essays. New York: The Macmillan Company, 1966. 